\title{
Otolith elemental composition reveals separate spawning areas of anchoveta, Engraulis ringens, off central Chile and northern Patagonia
}

\author{
María José Cuevas ${ }^{1,2}$, Konrad Górski ${ }^{3,4}$, Leonardo R. Castro ${ }^{2}$, Aurélien Vivancos ${ }^{5}$, \\ Malcolm Reid ${ }^{6}$ \\ ${ }^{1}$ Programa de Magíster en Ciencias con mención en Pesquerías, Universidad de Concepción, Chile. \\ (MJC) E-mail: mariajosecuevasc@ gmail.com. ORCID iD: https://orcid.org/0000-0001-7487-4905 \\ ${ }^{2}$ Centro COPAS Sur-Austral y Laboratorio de Oceanografía Pesquera y Ecología Larval (LOPEL), Departamento de \\ Oceanografía, Universidad de Concepción, Chile. \\ (LC) (Corresponding author) E-mail: lecastro@oceanografia.udec.cl. ORCID iD: https://orcid.org/0000-0001-7665-7883 \\ ${ }^{3}$ Departamento de Ecología, Facultad de Ciencias y Centro de Investigación en Biodiversidad y Ambientes Sustentables \\ (CIBAS), Universidad Católica de la Santísima Concepción, Concepción, Chile. \\ (KG) E-mail: konrad.gorski@uach.cl. ORCID iD: https://orcid.org/0000-0003-1154-7717 \\ ${ }^{4}$ Instituto de Ciencias Marinas y Limnológicas, Facultad de Ciencias, Universidad Austral de Chile, Valdivia, Chile. \\ ${ }^{5}$ Departamento de Sistemas Acuáticos, Facultad de Ciencias Ambientales, Universidad de Concepción, Concepción, Chile. \\ (AV) E-mail: aurelien.vivancos@ gmail.com. ORCID iD: https://orcid.org/0000-0002-3229-1047 \\ ${ }^{6}$ Department of Chemistry, University of Otago, New Zealand. \\ (MR) E-mail: malcolm.reid@otago.ac.nz. ORCID iD: https://orcid.org/0000-0002-4129-0214
}

\begin{abstract}
Summary: The anchoveta (Engraulis ringens) is widely distributed throughout the Humboldt Current $\left(4^{\circ} 30^{\prime}-44^{\circ} \mathrm{S}\right)$. In recent years, its eggs and larvae have also been found inside fjords and channels of northern Patagonia, close to the southern limit of the central-south Chilean fishery zone. Currently, it is unclear whether these southern individuals constitute an independent subpopulation. This study analysed the elemental composition of otoliths from 102 specimens from central Chile and northern Patagonia using laser ablation inductively coupled plasma mass spectrometry. The results indicated that the elemental composition of the otolith cores $(\mathrm{Mg}, \mathrm{Pb}, \mathrm{Zn}, \mathrm{Ba})$ differed significantly between sites, revealing the existence of two discrete spawning zones, one in central Chile and one in northern Patagonia. However, the low significant differences of elemental signatures of otolith edges suggest that either individuals from both areas move between spawning areas and mix at certain periods of the year, or they represent pocket units that form part of a larger stock that moves along the coast.
\end{abstract}

Keywords: LA-ICP-MS; anchovy; Humboldt Current; small pelagic fishes; Patagonia.

Composición elemental de otolitos revela áreas de desove separadas de la anchoveta, Engraulis ringens, en Chile central y en el norte de la Patagonia

Resumen: La anchoveta (Engraulis ringens), está ampliamente distribuida a lo largo de la Corriente de Humboldt $\left(4^{\circ} 30^{\prime}-\right.$ $44^{\circ} \mathrm{S}$ ). En años recientes, sus huevos y larvas han sido encontradas dentro de fiordos y canales del norte de la Patagonia, cerca del límite sur de la zona de pesca centro-sur chilena. Actualmente, no está claro si estos individuos del sur constituyen una subpoblación independiente. Este estudio analiza la composición elemental de otolitos de 102 especímenes de Chile central y Patagonia norte utilizando Ablación Láser con Espectrometría de Masas con Plasma Acoplado Inductivamente. Los resultados indican que la composición elemental $(\mathrm{Mg}, \mathrm{Pb}, \mathrm{Zn}, \mathrm{Ba})$ de los centros de los otolitos difieren significativamente revelando la existencia de dos zonas discretas de desove, una en Chile central y la otra en la Patagonia norte. Sin embargo, las escasas diferencias en las señales de los elementos en los bordes de los otolitos sugieren que los individuos de ambas áreas pueden moverse entre zonas de desove y mezclarse en ciertos periodos del año, o bien, que ellos representan unidades pequeñas que forman parte de un stock mayor que se mueve a lo largo de la costa.

Palabras clave: LA-ICP-MS; anchoveta; corriente de Humboldt; pequeños peces pelágicos; Patagonia.

Citation/Como citar este artículo: Cuevas M.J., Górski K., Castro L.R., Vivancos A., Reid M. 2019. Otolith elemental composition reveals separate spawning areas of anchoveta, Engraulis ringens, off central Chile and northern Patagonia. Sci. Mar. 83(4): 317-326. https://doi.org/10.3989/scimar.04918.28A

Editor: V.M. Tuset.

Received: February 8, 2019. Accepted: August 30, 2019. Published: November 12, 2019.

Copyright: (C) 2019 CSIC. This is an open-access article distributed under the terms of the Creative Commons Attribution 4.0 International (CC BY 4.0) License. 


\section{INTRODUCTION}

The anchoveta, Engraulis ringens (Jenyns, 1842), is a coastal pelagic anchovy that is widely distributed throughout the eastern Pacific Ocean, from northern Peru $\left(4^{\circ} 30^{\prime} \mathrm{S}\right)$ to Chiloé Island in southern Chile (44'14'S) (Serra 1983, Pauly and Tsukayama 1987), and is the target of one of the largest pelagic fisheries in the world. This species forms very dense shoals and is strongly influenced by biotic and abiotic environmental factors at all stages of its life cycle (Alheit and Niquen 2004). A number of early life history characteristics and reproductive traits, such as egg size, larval size and yolk sac size of recently hatched larvae of the anchoveta, have been described to vary along most of its range of distribution (Llanos-Rivera and Castro 2004, 2006, Castro et al. 2009). At its southern limit of distribution $\left(41^{\circ}\right.$ $44^{\circ} \mathrm{S}$ ), however, few studies of biology and ecology of adult anchoveta are available. The southern zone of the species distribution, named as the central-southern Chilean fishery zone for administrative purposes, covers a wide latitudinal range $\left(33^{\circ} \mathrm{S}\right.$ and $44^{\circ} \mathrm{S}$; Fig. 1) in which several historic spawning locations have been identified along the coast (Cubillos et al. 2005, 2006). In recent years, early developmental stages of anchoveta were found in the interior sea of Chiloé Island (northern Chilean Patagonia; $41^{\circ}-43^{\circ} \mathrm{S}$ ) (Landaeta and Castro 2006, Landaeta et al. 2009, Castro et al. 2015). Asynchrony and significant differences in spawning season have been documented within the central-southern Chilean fishery zone of anchoveta, where spawning occurs from July to December, with higher gonadosomatic indices from August to November below latitude $38^{\circ} \mathrm{S}$ and from September to October above latitude $38^{\circ} \mathrm{S}$ (Cubillos et al. 2009, Claramunt et al. 2014). Furthermore, significantly larger females have been found above latitude $38^{\circ} \mathrm{S}$ (Cubillos et al. 2009).

Evidence suggesting some spawning stock and population connectivity in this central-southern fishery has been proposed. Soto-Mendoza et al. (2012) used individually based models and concluded that a significant northward transport of eggs and larvae occurs from Corral (39 $\left.52^{\prime} \mathrm{S}\right)$ towards central Chile $\left(36^{\circ}-37^{\circ} \mathrm{S}\right)$. Other methodological approaches, including analyses of morphometrics, electrophoretic protein genetics, DNA and parasites (Ferrada et al. 2002, Valdivia et al. 2007, George-Nascimento et al. 2015), have been used to assess spawning stock structure of anchoveta from northern to central Chile but have not been conclusive (and have sometimes been contradictory) in terms of the number of stock units reported. The stock structure of this fishery remains poorly defined. Furthermore, it is unknown whether the individuals found in the interior/exterior sea of Chiloé Island constitute a separate unit (Zúñiga and Canales 2014) or are part of the central-southern fishery unit that migrates during the annual cycle.

Understanding of fish population structures and determination of discrete populations or spawning stock units is essential for sustainable management of fisheries resources (Sinclair 1988, Sinclair and Smith 2002, Cadrin et al. 2005). Spawning stock identifica- tion is a complex task in the pelagic environment. Most common methods for distinguishing between marine populations include analyses of morphometric variation, parasitic fauna, biological markers (gonadosomatic index and sexual maturity curve) and genetic markers (Cadrin et al. 2005). In recent years, trace element composition of otoliths has become a common and effective tool for identifying the spatial heterogeneity of populations and has helped identify migratory patterns and differentiate fish stocks (Hicks et al. 2010, Morais et al. 2010, Avigliano and Volpedo 2016). This technique is based on the fact that otoliths originate during the embryonic stage and grow continuously throughout the life of the fish. As they grow, otoliths show characteristic morphologic and chemical composition patterns. Otolith growth that occurred during the pelagic larval stage can be distinguished from growth during the juvenile or later adult period. The ability to correlate a particular part of an otolith with a discrete point in time is one of the most valuable aspects of this structure (Campana 1999, Chang and Geffen 2013, Górski et al. 2015). Furthermore, otoliths do not seem to experience chemical reabsorption for the majority of elements and therefore reflect the physico-chemical characteristics of water, forming a permanent record of the past environmental conditions experienced by fish (Bath et al. 2000, Rooker et al. 2003, Thorrold et al. 2007).

The objective of this study was to evaluate whether otolith elemental composition could indicate changes or persistence in habitats occupied by anchovetas and thereafter help to determine whether the central-south fishery of Chile can be divided into sub-units corresponding to different areas of spawning and growth or, alternatively, the level of mixing of specimens throughout the area shows that such sub-units did not exist. To address this question, the elemental composition of otoliths from individuals caught off central-southern Chile in 2014 and 2015 was analysed.

\section{METHODS}

\section{Sample locations and fish collection}

The study was conducted in the central-southern Chile fishery zone $\left(33^{\circ} \mathrm{S}-44^{\circ} \mathrm{S}\right)$ at two locations: Talcahuano (Thno., the central zone) and the Inner Sea of the Chiloé (ISCh, northern Patagonia). Mean satellite seasonal sea surface temperature was obtained along the central-southern Chilean coast, covering both sampling locations for the year of fish collections. Also, for longer term comparisons, an 11-year series (20052015) of mean sea surface temperature during the main spawning months (Thno, August-November; ISCh, September-October; Claramunt et al. 2014, Cubillos et al. 2009) in the Talcahuano zone $\left(36.48^{\circ} \mathrm{S} 72.98^{\circ} \mathrm{W}\right)$ and at the Inner Sea of Chiloé zone $\left(42.10^{\circ} \mathrm{S} 72.94^{\circ} \mathrm{W}\right)$ was obtained from satellite data. The satellite data were obtained from MODIS Aqua Globales (4 km pixel resolution) and downloaded from OceanColor Web (http://oceancolor.gsfc.nasa.gov/), and the images were processed in SeaDas (versión 7.3.2). 


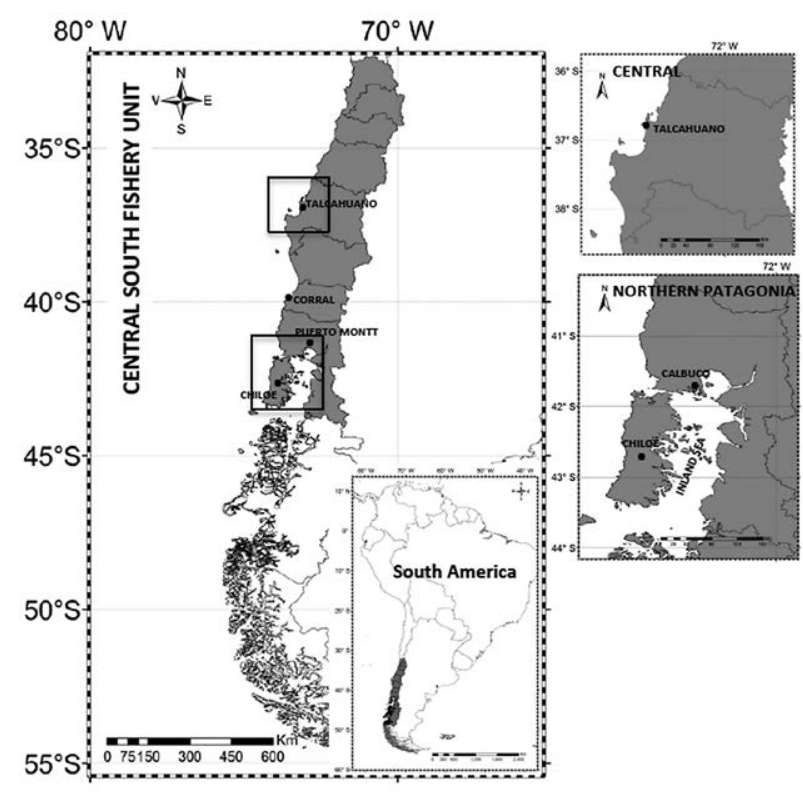

Fig. 1. - Engraulis ringens fishing zones (central and northern Patagonia) where the samples were obtained.

At both locations, specimens of Engraulis ringens were obtained from commercial catches in autumn and spring 2014 and summer 2015; only the general catch area was reported, as the exact catch locations are commercially sensitive (Fig. 1). Fish samples were selected at random. Subsequently, sex, weight and total length (TL) were recorded for each fish that was selected for otolith analysis. The fish were sorted into two age groups following the age-length key developed by Araya et al. (2008) and otolith ring counts. Group 1 included adult fish (11.5 and $13.4 \mathrm{~cm}$ TL; one year old) and Group 2 included adults larger than 13.4 $\mathrm{cm}$ TL (>two years old) (Table 1). Selected specimens were stored in a freezer $\left(-20^{\circ} \mathrm{C}\right)$ until analysis at the Fisheries Oceanography and Larval Ecology Laboratory (LOPEL) of the University of Concepción, Chile. Individuals obtained from the central zone and northern Patagonia were similar in size, ranging from 13.1 to $16.1 \mathrm{~cm}$ in the central zone and $13.1 \mathrm{~cm}$ to 15.6 $\mathrm{cm}$ in northern Patagonia. However, during April and January only individuals two years old or older were present, with the largest specimens being observed in April in the central zone (Table 1).

\section{Otolith preparation}

After the sagittal otoliths had been extracted from each fish and any adhering tissue had been cleaned away by rinsing with Milli-Q water, the dry samples were stored in $0.5 \mathrm{~mL}$ polypropylene micro tubes. The left otolith of each individual was then mounted on a glass slide with epoxy resin and sonicated. The slides were stored in polyethylene bags for later microchemical analysis.

\section{Microchemical analyses}

The elemental composition of each otolith was analysed using laser ablation inductively coupled mass
Table 1. - Month of collection, age group (1, adults 1 year; 2 , adults $>2$ years), catch zone, mean $( \pm$ S.D.), total length (TL) and number of Engraulis ringens individuals used for otolith microchemical analyses.

\begin{tabular}{|c|c|c|c|c|c|}
\hline \multirow[b]{2}{*}{ Month } & \multirow{2}{*}{ Group } & \multicolumn{2}{|c|}{ central zone } & \multicolumn{2}{|c|}{ northern Patagonia zone } \\
\hline & & No. of fish & $\mathrm{TL}(\mathrm{cm})$ & No. of fish & $\mathrm{TL}(\mathrm{cm})$ \\
\hline APR 2014 & 2 & 8 & $16.1 \pm 1.1$ & 10 & $15.1 \pm 1.6$ \\
\hline \multirow[t]{2}{*}{ OCT 2014} & 1 & 7 & $14.7 \pm 1.7$ & 10 & $13.1 \pm 0.6$ \\
\hline & 2 & 10 & $16.1 \pm 1.1$ & 5 & $15.7 \pm 1.4$ \\
\hline \multirow[t]{2}{*}{ NOV 2015} & 1 & 10 & $13.1 \pm 0.6$ & 2 & $12.7 \pm 0.7$ \\
\hline & 2 & 11 & $15.7 \pm 1.4$ & 10 & $15.6 \pm 1.4$ \\
\hline JAN 2015 & 2 & 10 & $15.7 \pm 1.4$ & 9 & $15.1 \pm 1.6$ \\
\hline
\end{tabular}

spectrometry (LA-ICP-MS) at the Centre for Trace Element Analysis at the University of Otago in Dunedin, New Zealand (the centre uses an ultraclean laboratory for analyses of this type). Depth profiles were obtained along ablation transects from the distal otolith surface (convex side), through the core, to the proximal surface (concave side) (Macdonald et al. 2008, Warburton et al. 2016). This was done using an ICP-MS Agilent 7500cs coupled to an ASI Resolution M-50 laser ablation system powered by a Coherent $193 \mathrm{~nm}$ ArF excimer laser.

The otoliths were mounted on a glass slide and the core was located visually through a video imaging system at $400 \times$ magnification. Each sample was ablated continuously in a cross section of the unpolished otolith using a 75 micron laser beam. The laser was operated at $5 \mathrm{~Hz}$ with an on-sample fluence of $2.2 \mathrm{~J} \mathrm{~cm}^{-2}$. Ablation occurred in an atmosphere of pure helium to minimize the re-condensation of the materials and potential elemental fractioning (Eggins et al. 1998). For each otolith ablation, data were collected for up to 450 seconds to ensure that the transect completely traversed the core. To reduce the delay time associated with cleaning, no signal smoothing collector was used (Woodhead et al. 2008). Count rate data were collected for the ions of the following isotopes: ${ }^{24} \mathrm{Mg},{ }^{31} \mathrm{P},{ }^{27} \mathrm{Al},{ }^{43} \mathrm{Ca},{ }^{55} \mathrm{Mn},{ }^{60} \mathrm{Ni}$, ${ }^{66} \mathrm{Zn},{ }^{88} \mathrm{Sr},{ }^{63} \mathrm{Cu},{ }^{85} \mathrm{Rb},{ }^{138} \mathrm{Ba}$ and ${ }^{208} \mathrm{~Pb}$. Concentrations of these elements are usually sufficiently high in the environment (Campana 1999). NIST 612 calibration glass and MACS-3 otolith reference material were run, bracketing groups of four otoliths.

\section{Data analyses}

Raw count rate data were reduced to molar ratios to calcium using the IOLITE software package (Iolitesoftware.com version 2.5). The means of the MACS-3 analyses were typically within $5 \%$ of the recommended values, with a precision generally better than $3 \%$ (relative standard deviation) for most elements. The relationship between $\mathrm{Ca}$ normalized concentrations of the elements $\mathrm{Mg}, \mathrm{Al}, \mathrm{P}, \mathrm{Mn}, \mathrm{Ni}, \mathrm{Zn}, \mathrm{Cu}, \mathrm{Rb}, \mathrm{Sr}, \mathrm{Ba}$ and $\mathrm{Pb}$ was recorded. $\mathrm{Mg}: \mathrm{Ca}$ and $\mathrm{P}: \mathrm{Ca}$ concentration are known to decrease throughout the ontogeny of sardine, because of physiological factors influencing the deposit rate of these elements on the otolith (Javor and Dorval 2016). This happened to also be the case in our data from anchoveta otoliths, as $\mathrm{Mg}: \mathrm{Ca}$ and $\mathrm{P}: \mathrm{Ca}$ were always strongly correlated over time (Pearson productmoment correlation $\mathrm{p}<00.1$ for each transect). Hence, $\mathrm{Mg}: \mathrm{Ca}$ and P:Ca often showed a "butterfly pattern" 


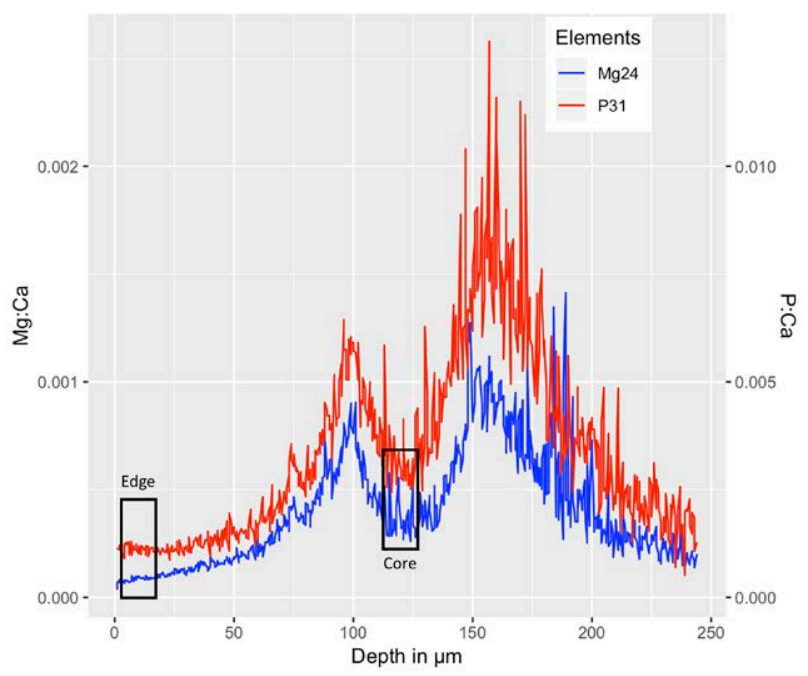

Fig. 2. $-\mathrm{Mg}: \mathrm{Ca}$ and $\mathrm{P}: \mathrm{Ca}$ ratios in relation to the ablation depth of the otolith of Engraulis ringens. Core and edge regions that were averaged for natal origin analyses are indicated.

on the otolith transects, with a high concentration at emergence, slowly decreasing over time and mirroring on each side of the nucleus. Therefore, we used the concentration of these elements to locate the nucleus on the transects (Fig. 2).

The element:calcium ratios were averaged for core and edge regions of each of the studied otoliths. For both edges and cores, $20 \mathrm{~s}$ of data were averaged, corresponding to 15 micrometres. Fifteen micrometre averages were used to ensure that only the early larval period was covered in core samples (Plaza and Cerna 2015). Mg:Ca and $\mathrm{P}: \mathrm{Ca}$ were always strongly correlated and therefore only $\mathrm{Mg}$ :Ca was used in the statistical analyses. A permutational multivariate analysis of variance (PERMANOVA, Anderson 2001) was used to determine differences in the element concentrations $(\mathrm{Mg}, \mathrm{Al}, \mathrm{Mn}$, $\mathrm{Ni}, \mathrm{Zn}, \mathrm{Cu}, \mathrm{Rb}, \mathrm{Sr}, \mathrm{Ba}, \mathrm{Pb}$ ) of the otoliths between catch zones and period of capture. This provided an analysis of variance for a set of explanatory factors based on dissimilarity measures, thereby allowing differences to be tested at a multivariate level and across a wide range of distributions of empirical data. The analyses were based on Euclidean distance matrices. The tests were performed separately for microchemical concentrations of the otolith edge and core.

Principal components analysis was used to illustrate differences in the multi-elemental composition of cores and edges of otoliths among samples ( $\mathrm{Mg}, \mathrm{Al}, \mathrm{Mn}, \mathrm{Ni}$, $\mathrm{Zn}, \mathrm{Cu}, \mathrm{Rb}, \mathrm{Sr}, \mathrm{Ba}$ and $\mathrm{Pb}$ ). Subsequently, data of each element were tested for normality and homogeneity of variance using the Shapiro-Wilk and Levene tests (original and $\log (\mathrm{x}+1)$-transformed data). Only ratios of $\mathrm{Sr}: \mathrm{Ca}, \mathrm{Mg}: \mathrm{Ca}, \mathrm{Ba}: \mathrm{Ca}, \mathrm{Zn}: \mathrm{Ca}, \mathrm{Rb}: \mathrm{Ca}$ and $\mathrm{Mn}: \mathrm{Ca}$ were normally distributed (Shapiro-Wilk test, $\mathrm{p}>0.05$ ) for both original and log-transformed data. However, only the $\mathrm{Sr}$ :Ca ratio met the assumption of homogeneity of variance (Levene test, $\mathrm{p}>0.05$ ). Therefore, differences between zones were tested using a non-parametric test (Kruskal-Wallis) followed by a Wilcoxon test. The differences were tested separately for cores and edges.

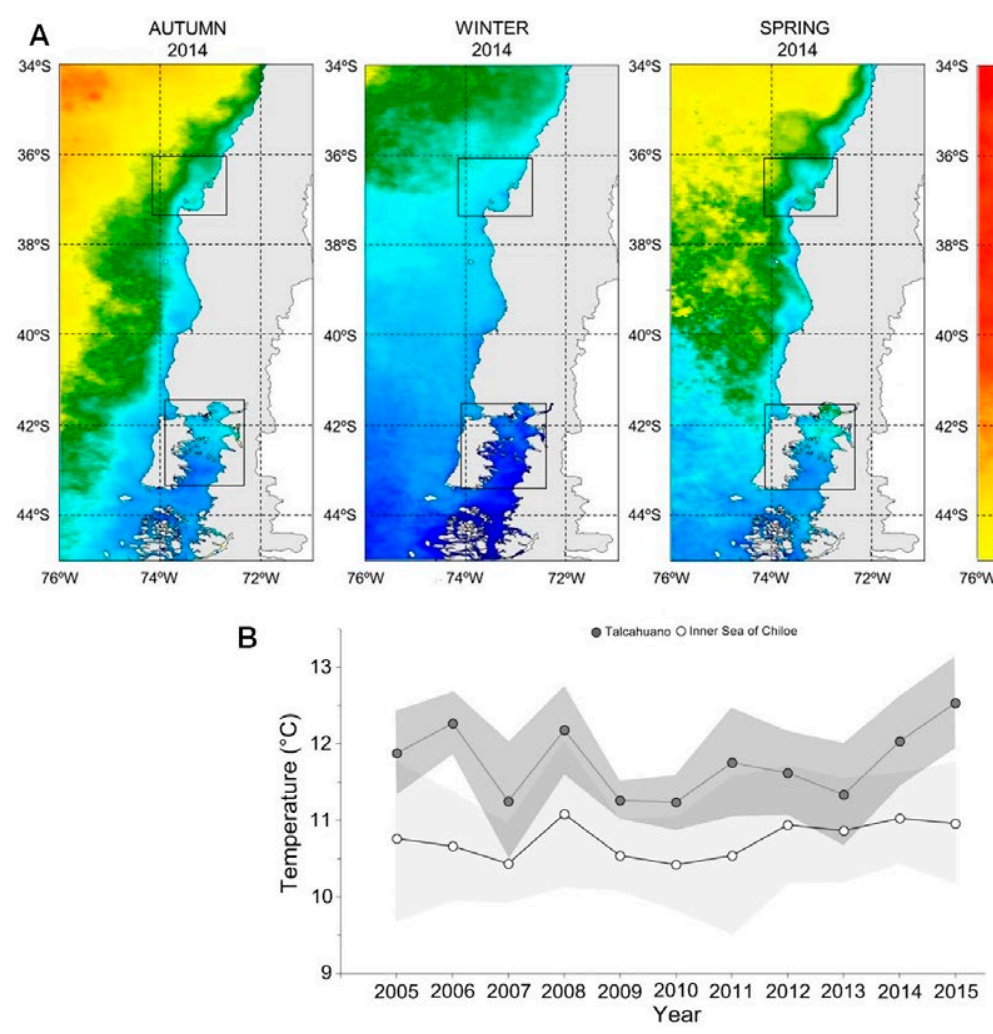

Fig. 3. - Seasonal satellite-obtained mean sea surface temperature along the central-southern Chilean coast showing the two zones (squares) of fish collection during the study (A). Time series (2005-2015) of mean surface temperature during the peak months of spawning in the two zones (Talcahuano, $36.48^{\circ} \mathrm{S} 72.98^{\circ} \mathrm{W}$; Inner Sea of Chiloé, $42.10^{\circ} \mathrm{S} 72.94^{\circ} \mathrm{W}$ ). Shaded area represents standard deviations (B). 
Table 2. - Results of the permutational multivariate analysis of variance based on a Euclidean distance matrix of the standardized concentrations of element/calcium ratios for $\mathrm{Mg}, \mathrm{Al}, \mathrm{Mn}, \mathrm{Ni}, \mathrm{Zn}, \mathrm{Sr}, \mathrm{Cu}, \mathrm{Rb}, \mathrm{Pb}$ and $\mathrm{Ba}$ in edges and cores of otoliths from Engraulis ringens caught off central Chile and northern Patagonia (obtained using 9999 permutations of residuals under a reduced model).

\begin{tabular}{|c|c|c|c|c|c|c|c|c|}
\hline \multirow[b]{2}{*}{ Source } & \multicolumn{4}{|c|}{ Edges } & \multicolumn{4}{|c|}{ Cores } \\
\hline & SS & Pseudo-F & $\mathrm{p}($ perm $)$ & No. perm & SS & Pseudo-F & $\mathrm{p}($ perm $)$ & No. perm \\
\hline Zone & $2 \mathrm{E}-07$ & 1.3 & NS & 9912 & $5 \mathrm{E}-05$ & 36.7 & $<0.001$ & 9911 \\
\hline Month & 2E-06 & 3.3 & NS & 9956 & $3 \mathrm{E}-05$ & 6,7 & $<0.001$ & 9957 \\
\hline Group & $2 \mathrm{E}-07$ & 1.4 & NS & 9935 & $5 \mathrm{E}-07$ & 0.4 & NS & 9906 \\
\hline Sex & $4 \mathrm{E}-09$ & 0.03 & NS & 9929 & $2 \mathrm{E}-07$ & 0.1 & NS & 9916 \\
\hline Zone $\times$ Month & $9 \mathrm{E}-07$ & 1.8 & NS & 9952 & $1 \mathrm{E}-05$ & 3.4 & NS & 9952 \\
\hline Zone $\times$ Group & $2 \mathrm{E}-07$ & 1.4 & NS & 9921 & $2 \mathrm{E}-07$ & 0.1 & NS & 9895 \\
\hline Zone $\times$ Sex & $2 \mathrm{E}-07$ & 1.1 & NS & 9951 & 9E-07 & 0.6 & NS & 9905 \\
\hline Month $\times$ Group & $1 \mathrm{E}-07$ & 0.7 & NS & 9927 & 2E-07 & 0.2 & NS & 9902 \\
\hline Month $\times$ Sex & $5 \mathrm{E}-07$ & 1.0 & NS & 9948 & $4 \mathrm{E}-06$ & 1.0 & NS & 9940 \\
\hline Group $\times$ Sex & $5 \mathrm{E}-08$ & 0.3 & NS & 9936 & 2E-06 & 1.1 & NS & 9917 \\
\hline Zone $\times$ Month $\times$ Group & $3 \mathrm{E}-08$ & 0.2 & NS & 9925 & $3 \mathrm{E}-08$ & 0.02 & NS & 9912 \\
\hline Zone $\times$ Month $\times$ Sex & $3 \mathrm{E}-07$ & 0.5 & NS & 9955 & $2 \mathrm{E}-06$ & 0.4 & NS & 9945 \\
\hline Zone $\times$ Group $\times$ Sex & $6 \mathrm{E}-08$ & 0.3 & NS & 9932 & 3E-07 & 0.2 & NS & 9902 \\
\hline Month $\times$ Group $\times$ Sex & $2 \mathrm{E}-07$ & 0.9 & NS & 9924 & $3 \mathrm{E}-07$ & 0.2 & NS & 9906 \\
\hline Residual & $1 \mathrm{E}-05$ & & & & 1E-04 & & & \\
\hline
\end{tabular}

\section{RESULTS}

Differences between locations and among seasons were observed in the mean seasonal sea surface temperature along the central-southern coast of Chile. In the Talcahuano area, temperatures were about $1^{\circ}$ to $2^{\circ} \mathrm{C}$ higher than in the Inner Sea of Chiloé area in all seasons (Fig. 3A). The 11-year time series of mean sea surface temperatures in the peak spawning months of anchoveta at each location also showed that mean temperature values fluctuated inter-annually, but mean temperatures in those months were consistently higher in the Talcahuano area than in the Inner Sea of Chiloé (Thno, $11.2^{\circ} \mathrm{C}-12.5^{\circ} \mathrm{C}$ vs. ISCh, $10.4^{\circ} \mathrm{C}-11.1^{\circ} \mathrm{C}$; $\chi_{0.05,1}^{2}, 22.80$, p<0.05) (Fig. 3B).

This study used a total of 102 adult Engraulis ringens specimens. Otoliths were extracted for laser ablation from 29 specimens that were one-year-old and from 73 that were two years old or older. In total, 56 specimens came from central Chile and 46 from northern Patagonia (Table 1). The concentrations of different trace elements at the otolith edges showed no significant differences in elemental concentrations for any of the factors (zone, month, group and sex; Table 2, Fig. 4). Furthermore, univariate tests for each of the elements separately revealed significant differences only for $\mathrm{Mg}(\mathrm{p}<0.05)$, which showed higher concentrations in the central zone than in northern Patagonia (Table 3, Fig. 5).

The PERMANOVA revealed significant differences in core elemental concentrations among zones and months (PERMANOVA; pseudo-F=36.7, $\mathrm{p}<0.001$, pseudo-F=6.7, $\mathrm{p}<0.001$ ) but not among age groups and sexes (Table 2, Fig. 4). April was the only month that did not differ between zones in pairwise comparisons ( $>0.05$; Table 4).

\section{EDGE}

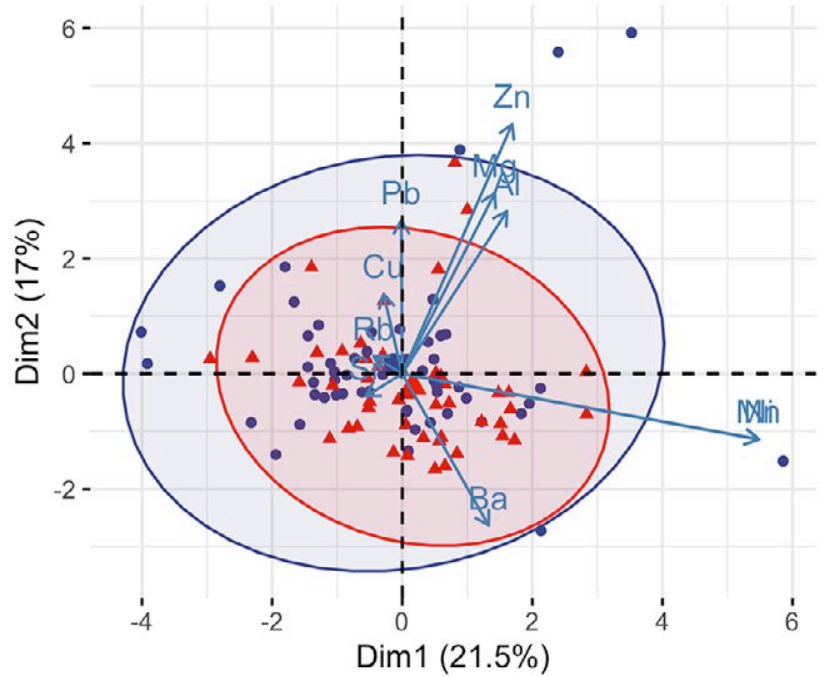

CORE

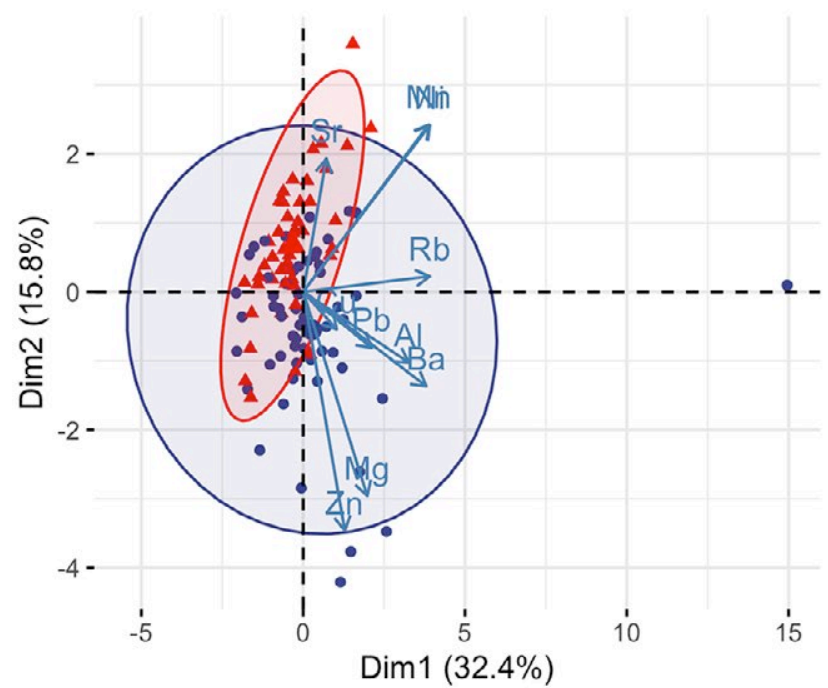

Groups central z.

$\triangle$ n-Patagonia z.

Fig. 4. - Principal component analysis ordination model of the otolith cores and edges with superimposed vectors of the element/calcium ratios. Element codes: Mg, magnesium; Zn, zinc; Pb, lead; Ba, barium; Sr, strontium; Al, aluminium; Mn, manganese; Ni, nickel; Cu, copper; $\mathrm{Rb}$, rubidium. Symbols identify the place of capture. 
Table 3. - Post-hoc univariate pairwise Wilcoxon test comparisons of element/calcium ratios in anchoveta otolith cores and edges between central Chile and northern Patagonia. Statistically significant values are indicated in bold.

\begin{tabular}{lcc}
\hline Element ratio & $\begin{array}{c}\text { Edge } \\
\text { Adjusted p-value }\end{array}$ & $\begin{array}{c}\text { Core } \\
\text { Adjusted p-value }\end{array}$ \\
\hline $\mathrm{Al}: \mathrm{Ca}$ & 0.191 & 0.691 \\
$\mathrm{Ba}: \mathrm{Ca}$ & 0.681 & $\mathbf{1 . 0 e - 1 0}$ \\
$\mathrm{Cu}: \mathrm{Ca}$ & 0.321 & 0.510 \\
$\mathrm{Mg}: \mathrm{Ca}$ & $\mathbf{1 . 4 e - 6}$ & $\mathbf{2 . 4 e - 1 0}$ \\
$\mathrm{Mn}: \mathrm{Ca}$ & 0.079 & 0.236 \\
$\mathrm{Ni}: \mathrm{Ca}$ & 0.078 & 0.226 \\
$\mathrm{~Pb}: \mathrm{Ca}$ & 0.121 & $\mathbf{0 . 0 2 7}$ \\
$\mathrm{Rb}: \mathrm{Ca}$ & 0.220 & 0.087 \\
$\mathrm{Sr}: \mathrm{Ca}$ & 0.651 & 0.432 \\
$\mathrm{Zn}: \mathrm{Ca}$ & 0.816 & 0.063 \\
\hline
\end{tabular}
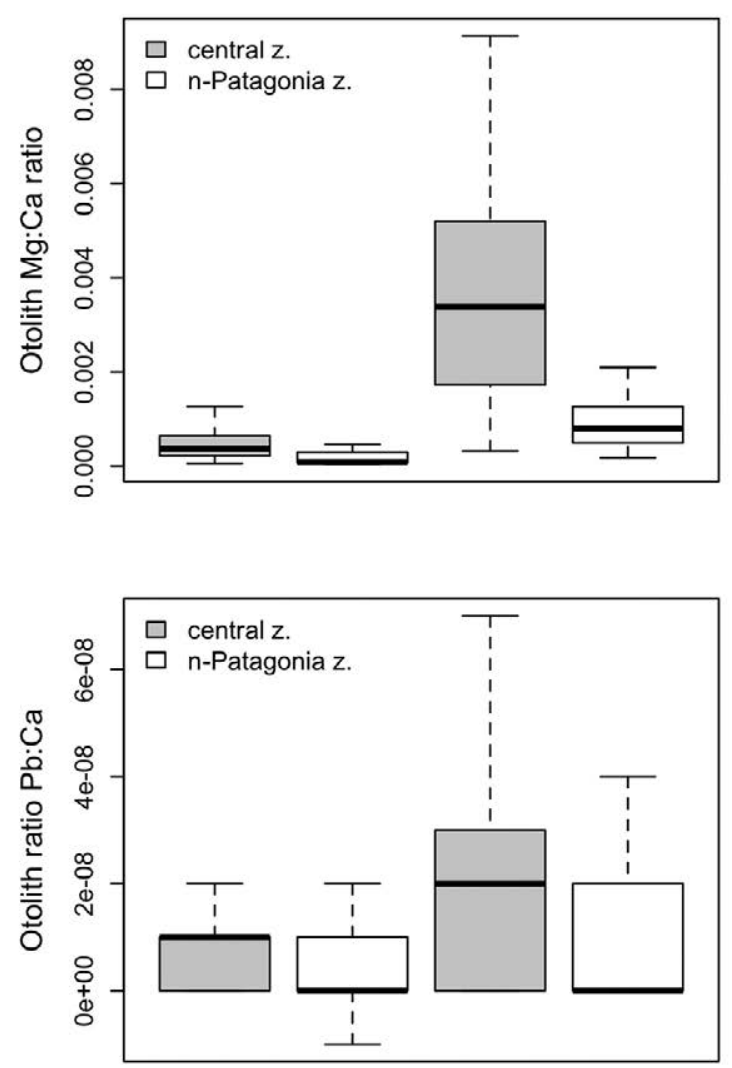

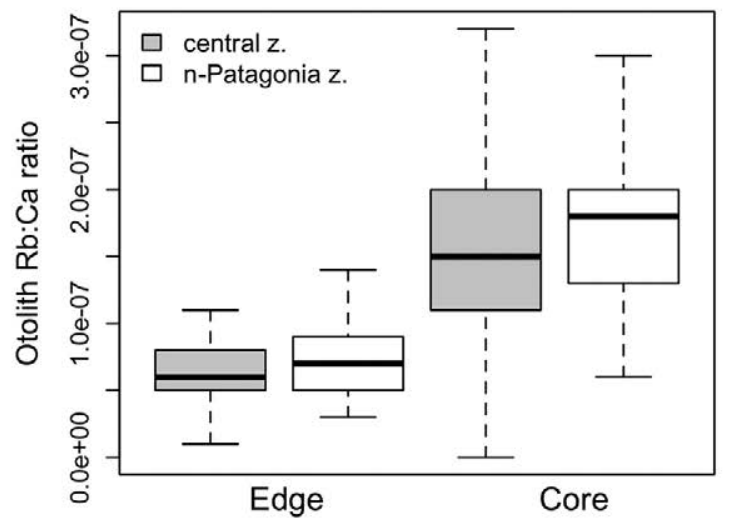

Table 4. - PERMANOVA pairwise tests of differences in multielemental concentrations in otolith cores between zones and months of sampling; $t$ and $p$ values were obtained using 9999 permutations of residuals under a reduced model.

\begin{tabular}{lcccc}
\hline Level & Zones & $\mathrm{t}$ & $\mathrm{p}$ (perm) & Unique perm \\
\hline APR & central Chile, northern Patagonia & 0.1 & $\mathrm{NS}$ & 9953 \\
OCT & central Chile, northern Patagonia & 6.5 & $<0.001$ & 9911 \\
NOV & central Chile, northern Patagonia & 4.4 & $<0.001$ & 9882 \\
JAN & central Chile, northern Patagonia & 3.1 & 0.001 & 9940 \\
\hline
\end{tabular}

Univariate analyses revealed differences between zones for some of the elements. Specifically, posthoc comparisons indicated significant differences between zones for $\mathrm{Ba}, \mathrm{Mg}$ and $\mathrm{Pb}(\mathrm{p}<0.05)$ and strong trends for $\mathrm{Rb}$ and $\mathrm{Zn}(\mathrm{p}<0.09)$ (Table 3, Fig. 5). Cores of otoliths of specimens from the central zone had

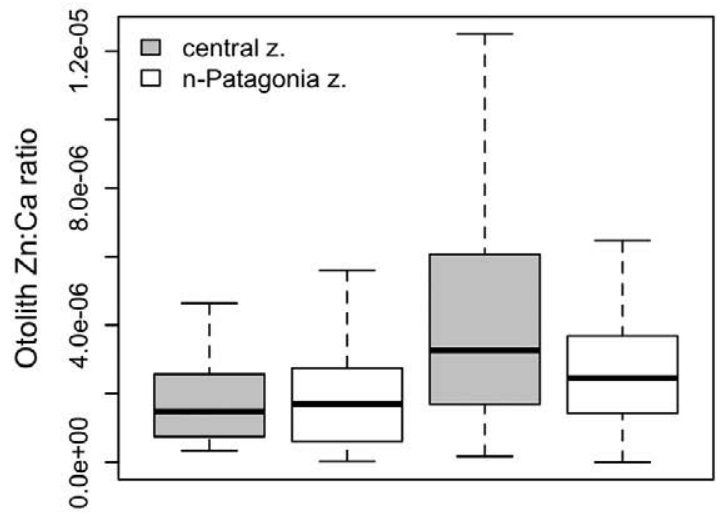

Edge

\section{Core}

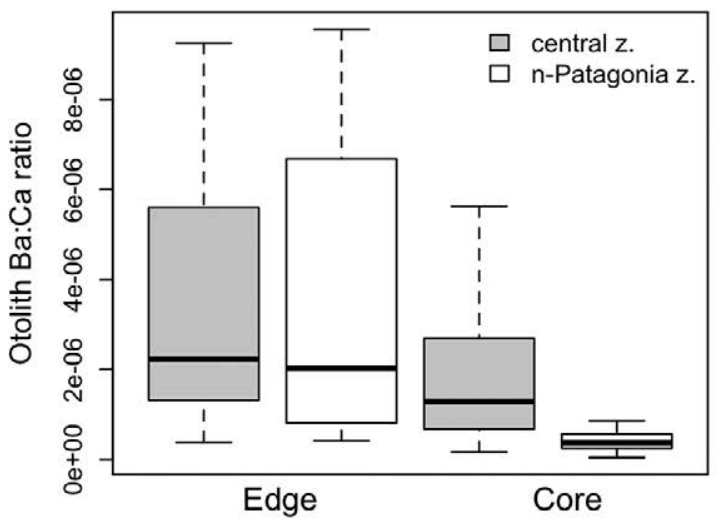

Fig. 5. - Box plot for $\mathrm{Mg}: \mathrm{Ca}, \mathrm{Ba}: \mathrm{Ca}, \mathrm{Pb}: \mathrm{Ca}, \mathrm{Zn}: \mathrm{Ca}$ and $\mathrm{Rb}: \mathrm{Ca}$ ratios for the edges and cores of the otoliths in the central zone and northern Patagonia. 
higher concentrations of $\mathrm{Ba}, \mathrm{Mg}, \mathrm{Pb}$ and $\mathrm{Zn}$ and lower concentrations of $\mathrm{Rb}$ than those of specimens from northern Patagonia.

\section{DISCUSSION}

The objective of this study was to evaluate whether the elemental composition of otoliths could serve as indicators of changes or of persistence in habitats occupied by the anchoveta Engraulis ringens and, thereafter, to determine whether the central-south fishery of Chile could be divided into sub-units corresponding to different areas of spawning and growth. The results showed significant differences in the elemental composition of otolith cores between the two fishing zones that form the central-south fishery, suggesting that there are two distinct spawning areas and that most individuals spent their early life stages in the area where they hatched. However, low differences in the elemental composition of otolith edges in some short periods indicated the possibility that adults from different origins mixed during the year.

In the otolith cores, the most important differences in terms of elemental composition were higher $\mathrm{Ba}, \mathrm{Mg}, \mathrm{Pb}$ and $\mathrm{Zn}$ concentrations in the central Chile zone than in northern Patagonia. In some fish species, magnesium has been positively associated with seawater temperature (Schuchert et al. 2010, Javor and Dorval 2017), which is consistent with the sea surface latitudinal temperature gradient along the Chilean coast, where warmer waters were found off central Chile $\left(>12^{\circ} \mathrm{C}\right)$ and colder waters occurred farther south $\left(<11.5^{\circ} \mathrm{C}\right)$. This pattern is consistent with our results of differences in sea surface temperatures among seasons and during the 11-year time series during the months of peak spawning at both locations, and has also been reported previously in other studies (Cubillos et al. 2015, Lillo et al. 2015). Similar to patterns observed in juvenile sardines Sardinops sagax (Javor and Dorval 2017), here we report a strong correlation of $\mathrm{Mg}: \mathrm{Ca}$ and P:Ca ratios for anchoveta Engraulis ringens. These concentrations were strong discriminants between sites with significant water temperature differences, and decreased throughout the ontogeny. Therefore, ontogenetic effects should be always considered when spatial patterns and stock structure of anchoveta are evaluated on the basis of microchemical signatures of otoliths.

We found higher concentrations of $\mathrm{Ba}$ in otolith cores from fish collected in central Chile (upwelling zone) than in those collected from northern Patagonia (a non-upwelling zone). Ba has a nutrient-like vertical distribution with much higher concentrations in deeper waters (Lea et al. 1989, Nozaki 2001), and its concentrations in surface waters significantly increase during upwelling events (Hsieh and Henderson 2017). Therefore, the higher $\mathrm{Ba}: \mathrm{Ca}$ ratios we found in fish in the central zone are most probably an effect of upwelling. These findings are concordant with previous observations of $\mathrm{Ba}: \mathrm{Ca}$ in seawater and fishes in other upwelling areas where increased $\mathrm{Ba}: \mathrm{Ca}$ has been detected under upwelling conditions (Wheeler et al. 2016, Hampton et al. 2018). A similar nutrient-like distribution might be expected for Sr (De Villiers 1999), though we found no significant differences in Sr:Ca rations in otoliths between central Chile and northern Patagonia. Wheeler et al. (2016) concluded that individual ratios of Sr:Ca in fish otoliths showed little variation in the California upwelling system and did not serve as valuable proxies of oceanic conditions.

Regarding other elements, off central Chile, Ahumada (1995) found higher metal concentrations $(\mathrm{Pb}$, $\mathrm{Zn}, \mathrm{Cu}, \mathrm{Cr}$, Ni and $\mathrm{Cd}$ ) from anthropogenic origins in San Vicente Bay (central Chile, 36 $44^{\prime} \mathrm{S}, 7^{\circ} 09^{\prime} \mathrm{W}$ ). Reports from other bays in the same area were consistent with these results. For example, $\mathrm{Pb}$ was the predominant trace metal found in the seawater of Concepción Bay (central Chile; 36 $40^{\prime} \mathrm{S}, 73^{\circ} 01^{\prime} \mathrm{W}$ ) (Carrera et al. 1993). The greater concentrations of $\mathrm{Pb}$ and $\mathrm{Zn}$ recorded in the anchoveta otolith cores from central Chile in this study might be a result of high heavy metals recorded for this area traced to nearby iron, steel and petrochemical industries. Zinc concentrations in otoliths have previously been used to indicate particular habitats because they are influenced by fish diet (Ranaldi and Gagnon 2008) and tends to be higher in urban coastal zones due to anthropogenic sources (Sturrock et al. 2012).

Unlike the elemental concentrations of the otolith cores of anchoveta, elemental concentrations of the otolith edges did not differ between zones. There are at least three potential explanations for these core differences and edge similarities in elemental composition. Differences among cores and similar edge concentrations might occur if the adult habitat is environmentally heterogeneous, wide in extension and covering inshore and offshore zones, but the spawning habitat where small larvae occur is restricted to the coastal zone given their limited swimming capacities. These across-shelf ontogenetic differences in elemental composition have been observed in other anchovy species in other systems (e.g. E. encrasicolus in the Gulf of Cadiz; Catalán et al. 2014). Under this scenario, if environmental conditions inshore in central Chile and northern Patagonia differ significantly but are similar offshore, the otolith edge elemental concentrations might not differ between individuals collected in the two zones, while their otolith core concentrations might. Heavy metal concentrations are usually reported to be several times higher in coastal than in oceanic waters due to greater continental contributions from urban areas or sites of high industrial concentration (Luoma 1990, Giordano et al. 1992, French 1993). In our study, besides $\mathrm{Ba}$, these higher concentrations allowed us to infer the presence of two discrete spawning grounds. Prior research cruises (September-October 2009, 2010 and 2012; Cubillos et al. 2010, 2011, 2013) verified that, spatially, spawning grounds occur in coastal areas not exceeding 15 nautical miles offshore. However, larger individuals could be found as far as 30 to 40 nautical miles from the coastal spawning grounds, as depicted from the current industrial fishing areas. Consequently, across-shelf movements would homogenize elemental composition differences in the otolith edges of older fishes. 
A second explanation might be that the greater swimming capacity of the larger individuals might allow them to migrate north and south, could they could sometime access other spawning grounds where they would mix with specimens from local spawning and nursery areas. If this movement were frequent and involved large fractions of the populations, differences in the core elemental composition would tend to decrease significantly, and any difference in edge elemental composition (such as $\mathrm{Mg}$, Table 4) indicative of different environmental temperature regimes probably associated with latitude should vanish. In this study during autumn (April), only adult fish older than one year of age were analysed (Table 1), and no differences were observed in core elemental composition between individuals from the two analysed zones. This suggests that adult individuals from both zones might mix before returning to the spawning habitats. This pattern of segregation of population units and a short period of mixing in some seasons is common in a number of fish species displaying homing behaviour associated with estuarine conditions, e.g. Engraulis encrasicolus L. in the Mediterranean Sea (Aldanondo et al. 2010, Guidetti et al. 2013).

A third potential explanation is that these two spawning units represent pocket populations of a broader stock that migrates and that might shift from year to year depending on annual variations in temperature, prey abundance or other undetermined factors. Unfortunately, because the length of our data series is relatively short (one year), we cannot make strong inferences on the restricted or periodical movements across several years. In other systems, elemental differentiation has been observed in cohorts of small pelagic fishes in some years but not in others (Guidetti et al. 2013). While changes in the main spawning locations along the central-southern fishery zone have been reported at 5- to 10-year periods or longer (Bernal et al. 1983, Serra 1983, Castro et al. 1997), shorter-term (inter-annual) changes in migration patterns have not been reported for anchoveta units along their southern distribution range.

In summary, this study of the elemental composition of otoliths provides evidence of two discrete spawning areas of Engraulis ringens along the centralsouth fishery zone: one in central Chile and one in northern Patagonia, and mixing of adults during some non-spawning periods of the year. This finding agrees with the spatial and structural asynchrony in the reproductive processes in the two areas. Future studies should assess whether this pattern is consistent year to year or varies over longer time periods.

\section{AKNOWLEDGEMENTS}

This study was financed by the CONICYT Basal Programme COPAS Sur-Austral PIA PFB31. During the study, the first author was supported by graduate fellowships from CONICYT and COPAS Sur-Austral CONICYT PIA PFR31. LC was also supported by COPAS Sur-Austral CONICYT PIA APOYO CCTE AFB170006 and FONDECYT 1161131. The authors thank J. Betzhold, G. Vásquez, and R. Riffo for collections at the artisanal fishery port and vessels and colleagues at the Laboratorio de Oceanografía Pesquera y Ecología Larval (LOPEL) at the Universidad de Concepción for technical support.

\section{REFERENCES}

Ahumada R. 1995. Bahías: Áreas de uso múltiple un enfoque holístico del problema de contaminación. Cien. Tecnol. Mar, CONA. Número Especial, 59-68.

Alheit J., Niquen M. 2004. Regime shift in the Humboldt Current ecosystem. Prog. Oceanogr. 60: 201-222. https://doi.org/10.1016/j.pocean.2004.02.006

Aldanondo N., Cotano U., Tiepolo M., et al. 2010. Growth and movement patterns of early juvenile European anchovy (Engraulis encrasicolus L.) in the Bay of Biscay based on otolith microstructure and chemistry. Fish. Oceanogr. 19: 196-208. https://doi.org/10.1111/j.1365-2419.2010.00537.x

Anderson M. 2001. A new method for non-parametric multivariate analysis of variance. Austral Ecol. 26: 32-46. https://doi.org/10.1111/j.1442-9993.2001.01070.pp.x

Araya M., Cubillos L., Peñailillo J. 2008. Validación de la edad de la anchoveta en la costa de Chile. Informe final Proyecto FIP/2004-38. Fondo de Investigación Pesquera, Chile. pp 138.

Avigliano E., Volpedo A. 2016. A Review of the Application of Otolith Microchemistry Toward the Study of Latin American Fishes. Rev. Fish. Sci. Aquac. 24: 369-384. https://doi.org/10.1080/23308249.2016.1202189

Bath G., Thorrold S., Jones C., et al. 2000. Strontium and barium uptake in aragonitic otoliths of marine fish. Geochim. Cosmochim. Acta 64: 1705-1714. https://doi.org/10.1016/S0016-7037(99)00419-6

Bernal P.A., Robles F.L., Rojas O. 1983. Variabilidad física y biológica en la región meridional del sistema de corrientes ChilePeru. FAO Fish Rep. 291: 683-711

Cadrin S., Friedland K., Waldman J. 2005. Stock Identification Methods: Applications in Fishery Science. Elsevier Academic Press, London, 719 pp

Campana S. 1999. Chemistry and composition of fish otoliths: pathways, mechanisms and applications. Mar. Ecol. Prog. Ser. 188: 263-297.

https://doi.org/10.3354/meps 188263

Castro L., Quiñones R., Arancibia H., et al. 1997. Areas de desove de anchoveta y sardina común en Chile central. Informe Técnico FIP-IT/96-11. Fondo de Investigación Pesquera. Subsecretaría de Pesca, 235 pp.

Castro L.R., Claramunt G., Krautz M.C., et al. 2009. Egg trait variations in anchoveta Engraulis ringens: A maternal effect to changing environmental conditions in contrasting spawning habitats. Mar. Ecol. Prog. Ser. 381: 237-248. https://doi.org/10.3354/meps07922

Castro L., Soto S., Llanos A., et al. 2015. Identification of spawning zones and early life stages of small pelagic fishes in inshore waters of the X and XI regions, year 2013. FIP 2013-17 Final Research Report (in Spanish). Fondo de Investigación Pesquera, Chile. 414 pp.

Carrera M., Rodríguez V., Ahumada R., et al. 1993. Metales trazas en la columna de agua y sedimentos blandos en Bahía de Concepción, Chile. Determinación mediante voltametría de redisolución. Rev. Biol. Mar. Oceanogr. 28: 151-163.

Catalán I.A., Pérez-Mayol S., Alvarez I., et al. 2014. Daily otolith growth and ontogenetic geochemical signatures of age-0 anchovy (Engraulis encrasicolus) in the Gulf of Cadiz (SW Spain). Mediterr. Mar. Sci. 15: 781-789. https://doi.org/10.12681/mms.819

Chang M., Geffen A. 2013. Taxonomic and geographic influences on fish otolith microchemistry. Fish Fish. 14: 458-492. https://doi.org/10.1111/j.1467-2979.2012.00482.x

Claramunt G., Cubillos L.A., Castro L., et al. 2014. Variation in the spawning periods of Engraulis ringens and Strangomera bentincki off the coasts of Chile: A quantitative analysis. Fish. Res. 160: 96-102. https://doi.org/10.1016/j.fishres.2013.09.010

Cubillos L., Castro L., Oyarzún C. 2005. Evaluación de stock desovante de anchoveta y sardina común entre la V y X Regiones, año 2004, Informe Técnico Proyecto FIP-IT/2004-03, Instituto de Fomento Pesquero, Chile, $130 \mathrm{pp}$. 
Cubillos L., Castro L., Claramunt G., et al. 2006. Evaluación de stock desovante de anchoveta y sardina común entre la $\mathrm{V}$ y $\mathrm{X}$ Regiones, año 2005, Informe Técnico Proyecto FIP-IT/2005-02. Instituto de Fomento Pesquero, Chile, $147 \mathrm{pp}$.

Cubillos L., Pedraza M., Canales M., et al. 2009. Dinámica reproductiva de anchoveta y sardina común, zona centro-sur año 2006. Informe final Proyecto FIP/2006-13. Instituto de Fomento Pesquero, Chile, $141 \mathrm{pp}$

Cubillos L.A., Castro L., Claramunt G., et al. 2010. Evaluación del Stock Desovante de Anchoveta y Sardina común entre la V y X Región, año 2009. Informe Final Proyecto FIP/2009-08. Instituto de Fomento Pesquero, Chile, 129 pp.

Cubillos L.A., Castro L., Claramunt G. 2011. Evaluación del Stock Desovante de anchoveta y sardina común entre la V y X Región, año 2010. Informe Final Proyecto FIP/2010-02. Instituto de Fomento Pesquero, Chile, $125 \mathrm{pp}$

Cubillos L.A., Castro L., Claramunt G., et al. 2013. Evaluación del stock desovante de anchoveta y sardina común entre la V y X Regiones, año 2012. Informe Final Proyecto FIP/2012-09. Instituto de Fomento Pesquero, Chile, $151 \mathrm{pp}$

Cubillos L.A., Castro L., Claramunt G., et al. 2015. Evaluación del stock desovante de anchoveta y sardina común entre la $\mathrm{V}$ y $\mathrm{X}$ Regiones, año 2014. Instituto de Fomento Pesquero, Chile, 212 pp.

De Villiers S. 1999. Seawater strontium and Sr/Ca variability in the Atlantic and Pacific oceans. Earth Planet. Sci. Lett. 171: 623-634. https://doi.org/10.1016/S0012-821X(99)00174-0

Eggins S., Kinsley L., Shelley J. 1998. Deposition and fractionation processes during atmospheric pressure laser sampling for analysis by ICP-MS. Appl. Surf. Sci. 127-129: 278-286. https://doi.org/10.1016/S0169-4332(97)00643-0

Ferrada S., Hernández K., Montoya R., et al. 2002. Estudio poblacional del recurso anchoveta (Engraulis ringens Jenyns 1842) (Clupeiformes, Engraulidae), mediante análisis de ADN. Gayana 66: 243-248. https://doi.org/10.4067/S0717-65382002000200022

French P. 1993. Post-industrial pollutant levels in contemporary Svern estuary intertidal sediments compared to pre-industrial levels. Mar. Poll. Bull. 26: 30-35. https://doi.org/10.1016/0025-326X(93)90594-A

George-Nascimento M., Oliva M. 2015. Fish population studies using parasites from the Southeastern Pacific Ocean: considering host population changes and species body size as sources of variability of parasite communities. Parasitology 142: 25-35. https://doi.org/10.1017/S0031182014001127

Guidetti P., Petrillo M., De Benedetto G., et al. 2013. The use of otolith microchemistry to investigate spawning patterns in European anchovy: a case study in the Eastern Ligurian Sea (NW Mediterranean). Fish. Res. 139: 1-4. https://doi.org/10.1016/j.fishres.2012.10.015

Giordano P., Musmeci L., Ciaralli P., et al. 1992. Total content and sequential extractions of $\mathrm{Hg}, \mathrm{Cd}$ and $\mathrm{Pb}$ in coastal sediments. Mar. Pol. Bull. 40: 1042-1050.

Górski K., De Gruijter C., Tana R. 2015. Variation in habitat use along the freshwater-marine continuum by grey mullet Mugil cephalus at the southern limits of its distribution. J. Fish Biol. 87: 1059-1071. https://doi.org/10.1111/jfb.12777

Hampton S.L., Maloney C.L., van der Lingen C.D., et al. 2018. Spatial and temporal variability in otolith elemental signatures of juvenile sardine off South Africa. J. Mar. Sys. 188: 109-116. https://doi.org/10.1016/j.jmarsys.2018.02.001

Hicks A., Closs G., Swearer S. 2010. Otolith microchemistry of two amphidromous galaxiids across an experimental salinity gradient: a multi-element approach for tracking diadromous migrations. J. Exper. Mar. Biol. Ecol. 394: 86-97. https://doi.org/10.1016/j.jembe.2010.07.018

Hsieh Y.T., Henderson G.M. 2017. Barium stable isotopes in the global ocean: Tracer of $\mathrm{Ba}$ inputs and utilization. Earth Planet Sci. Lett. 473: 269-278. https://doi.org/10.1016/j.eps1.2017.06.024

Javor B.J., Dorval E. 2016. Stability of trace elements in otoliths of juvenile Pacific sardine Sardinops sagax. CalCOFI Rep. 57: 109-123.

Javor B.J., Dorval E. 2017. Composition and inter-annual variability in trace element profiles of Pacific sardine otoliths. CalCOFI Rep. 58: 95-104.

Landaeta M.F., Castro L.R. 2006. Seasonal variability in the spatial patterns of ichthyoplanktonic assemblages from the fjord zone of austral Chile. Cien. Tecnol. Mar. 29: 107-127.

Landaeta M., Muñoz M.I., Castro L.R. 2009. Seasonal and shortterm variability in the vertical distribution of ichthyoplankton in a stratified fjord of southern Chile. Cien. Tecnol. Mar. 32: 27-42.

Lea D.W., Shen G.T., Boyle E.A. 1989. Coralline barium records temporal variability in Equatorial Pacific upwelling. Nature 340: $373-376$ https://doi.org/10.1038/340373a0

Lillo S., Lang C., Molina E., et al. 2015. Evaluación hidroacústica de pequeños pelágicos en aguas interiores de la X y XI Regiones, año 2014. Informe Final Proyecto Convenio desempeño 2014. Instituto de Fomento Pesquero, Chile, 161 pp.

Llanos-Rivera A., Castro L.R. 2004. Latitudinal and seasonal egg size variations of the anchoveta Engraulis ringens off the Chilean Coast. Fish. Bull. 102: 207-212.

Llanos-Rivera A., Castro L.R. 2006. Inter-population differences in temperature effects on Engraulis ringens yolk-sac larvae. Mar. Ecol. Prog. Ser. 312: 245-253. https://doi.org/10.3354/meps312245

Luoma S. 1990. Processes affecting metal concentrations in estuarine and coastal sediments. In: Furnes R., Rainbow P. (eds), Heavy Metals in the Marine Environment. CRC Press. New York, pp. 51-66.

Macdonald J., Shelley M., Crook D. 2008. A Method for Improving the Estimation of Natal Chemical Signatures in Otoliths. Trans. Amer. Fish. Soc. 137: 1674-1682 https://doi.org/10.1577/T07-249.

Morais P., Babaluk J., Correia A., et al. 2010. Diversity of anchovy migration patterns in a European temperate estuary and in its adjacent coastal are: Implications for fishery management. J. Sea Res. 64: 295-303. https://doi.org/10.1016/j.seares.2010.04.001

Nozaki Y. 2001. Elemental distribution. In: Steele J.H., Thorpe S.A., Turekian K.K. (eds), Encyclopedia of Ocean Sciences. Academic Press, San Diego, CA. pp. 840-845. https://doi.org/10.1006/rwos.2001.0402

Pauly D., Tsukayama I. 1987. The Peruvian Anchoveta and its Upwelling Ecosystem: Three Decades of Change. ICLARM Studies and Reviews, $351 \mathrm{pp}$.

Plaza G., Cerna F. 2015. Validation of daily microincrement deposition in otoliths of juvenile and adult Peruvian anchovy Engraulis ringens. J. Fish Biol. 86: 203-216. https://doi.org/10.1111/jfb.12561

Ranaldi M., Gagnon M. 2008. Zinc incorporation in the otoliths of juvenile pink snapper (Pagrus auratus Forster): The influence of dietary versus waterborne sources. J. Exper. Mar. Biol. Ecol. 360: 56-62. https://doi.org/10.1016/j.jembe.2008.03.013

Rooker J., Secor D., Zdanowicz V., et al. 2003. Identification of Atlantic bluefin tuna (Thunnus thynnus) stocks from putative nurseries using otolith chemistry. Fish. Oceanogr. 12: 75-84. https://doi.org/10.1046/j.1365-2419.2003.00223.x

Serra J.R. 1983. Changes in the abundance of pelagic resources along the Chilean coast. In: Sharp G., Csirke J. (eds), Proceedings of the Expert Consultation to Examine Changes in Abundance and Species Composition of Neritic Fish Resources. FAO Fish. Rep. 291: 255-284.

Sinclair M. 1988. Marine populations: an essay on population regulation and speciation. Washington Sea Grant Program, Seattle, Washington, $252 \mathrm{pp}$.

Sinclair M.M., Smith T.D. 2002. The notion that fish species form stocks. ICES Mar. Sci. Symp. 215: 297-304.

Soto-Mendoza S., Parada C., Castro L., et al. 2012. Modelling transport and survival of anchoveta eggs and yolk-sac larvae in the coastal zone off central-southern Chile: Assessing spatial and temporal spawning parameters. Prog. Ocean. 92: 178-191. https://doi.org/10.1016/j.pocean.2011.07.001

Schuchert P., Alexander I., Arkhipkin E., et al. 2010. Traveling around Cape Horn: Otolith chemistry reveals a mixed stock of Patagonian hoki with separate Atlantic and Pacific spawning grounds. Fish. Res. 102: 80-86. https://doi.org/10.1016/j.fishres.2009.10.012

Sturrock A., Trueman C., Darnaude A., et al. 2012. Can otolith elemental chemistry retrospectively track migrations in fully marine fishes? J. Fish Biol. 81: 766-795. https://doi.org/10.1111/j.1095-8649.2012.03372.x

Thorrold S., Zacherl C., Levin L. 2007. Population Connectivity and Larval Dispersal, Using Geochemical Signatures in Calcified Structures. Oceanography 20: 80-89. 
https://doi.org/10.5670/oceanog.2007.31

Valdivia I., Chávez A., Oliva E. 2007. Metazoan parasites of Engraulis ringens as tools for stock discrimination along the Chilean coast. J. Fish Biol. 70: 1504-1511.

https://doi.org/10.1111/j.1095-8649.2007.01429.x

Warburton M., Reid M., Stirling C., et al. 2016. Validation of depthprofiling LA-ICP-MS in otolith applications. Can. J. Fish. Aquat. Sci. 74: 572-581. https://doi.org/10.1139/cjfas-2016-0063

Wheeler S.G., Russel A.D., Fehrerenbacher J.S., et al. 2016. Evaluating chemical signatures in a costal upwelling region to reconstruct water mass associations of settlement-stage rockfishes. Mar. Ecol. Prog. Ser. 550: 191-206.

https://doi.org/10.3354/meps 11704
Woodhead J., Hellstrom J., Paton C., et al. 2008. A guide to depth profiling and imaging applications of LA-ICP-MS. In: Sylvester P. (ed), Laser Ablation ICP-MS in the Earth Sciences: Current Practices and Outstanding Issues; Short Course 40; Mineralogical Association of Canada: Quebec City, QC, Canada, pp. $135-145$.

Zúñiga M.J., Canales C. 2014. Investigación del estatus y posibilidades de explotación biológicamente sustentables anchoveta zona centro-sur, año 2014. Cuarto Informe Proyecto 2.5. Instituto de Fomento Pesquero, Chile. 81 pp. 